\title{
AN EXAMINATION OF STUDENT SUCCESS WITHIN CANADIAN HIGHER EDUCATION: FIFTY YEARS OF FINDINGS AND RECOMMENDATIONS FOR THE FUTURE
}

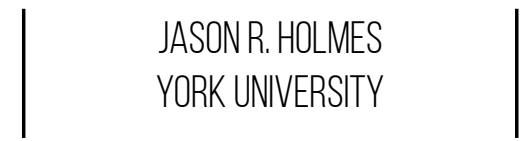

\section{Abstract}

This article explores the student success literature published within the Canadian Journal of Higher Education (CJHE) over the last fifty years. Sixty articles were thematically organized into seven component measures of student success to present consistent themes that have persisted within the CJHE from inception in 1971 to 2020. Analysis demonstrates that there has been a disproportionate interest in some aspects of student success such as post-college performance, while other areas such as educational attainment and student engagement have lagged considerably behind in focus. Scholars have presented ongoing concerns supported by a wide range of data regarding the underemployment of graduates from Arts and Humanities, the sparse professorial landscape and the underutilization of Canadian PhD graduates in the workforce, debate on student competence and skill measurement, and the lack of large data sets on student persistence. Results suggest that a continuous effort is required to understand and support student success in a variety of formats-both within the academy and out in the workforce. Thus, this article concludes with a discussion and recommendations for future research avenues in the field of academic success and various subfields that may be of interest to higher education scholars and those who support student success.

Keywords: student success, higher education, post-secondary outcomes, literature review, Canada

\section{Résumé}

Cet article explore la littérature sur la réussite étudiante publiée dans la Revue canadienne d'enseignement supérieur (RCES) au cours des cinquante dernières années. Soixante articles ont été classés par thème selon sept composantes de la réussite étudiante afin de présenter des thèmes cohérents qui ont persisté dans la RCES depuis sa création en 1971 et jusqu'en 2020. Cette catégorisation démontre qu'il y a eu un intérêt disproportionné pour les aspects de la réussite des étudiants tels que la performance après les études, alors que d'autres domaines tels que le niveau d'éducation et l'engagement étudiant sont restés considérablement en retrait. Les chercheurs ont présenté des préoccupations constantes, appuyées par un large éventail de données, concernant le sous-emploi des diplômés en arts et en sciences humaines; la rareté des postes de professeur et la sous-utilisation des diplômés canadiens du doctorat; le débat sur la mesure des compétences et des aptitudes des étudiants; et le manque de grands ensembles de données sur la persévérance des étudiants. Les résultats suggèrent qu'un effort continu est nécessaire pour comprendre et soutenir la réussite étudiante dans une variété de formats, à l'intérieur et à l'extérieur de l'université. Ainsi, cet article se termine par une discussion sur des pistes de recherche dans le domaine de la réussite universitaire qui pourraient intéresser les chercheurs en enseignement supérieur.

Mots-clés : réussite étudiante, enseignement supérieur, résultats des études postsecondaires, revue de la littérature, Canada

\section{Introduction}

The study of success in any field presents numerous challenges as simply defining the concept can vary from the societal to the individual level. Within post-secondary education, understanding and fostering the success of our students is of critical importance, as the complexities of the social, cultural, economic, and political landscapes 
often require some form of post-secondary education for individuals to be successful. Unsurprisingly, the study of student success is vastly complex and multidimensional, as there are various components one may explore when attempting to measure such a subjective term.

There are many avenues of exploration when seeking to grasp the concept of student success. For example, we may look at wage premiums for undergraduate completion and discern that degree completion is paramount for success, as holding a bachelor's degree equates to higher earnings over one's life when compared to high-school completion (Frenette, 2014; Pascarella \& Terenzini, 2005). Further, we might argue that if degree completion and subsequent economic benefits are the goal, then understanding and supporting student persistence and retention within higher education are key factors of success (Dooley et al., 2012; Mueller, 2008). Also, with the diversity present within Canada and many other societies, we may argue that addressing social inequality through access to higher education and supporting subsections that are underrepresented is a key metric to gauge success (Michalski et al., 2017). In order to achieve any of the aforementioned goals, we need to understand a wide range of psychological factors that could affect success such as self-esteem, anxiety, and depression (Lisnyj et al., 2020; Wasylkiw et al., 2020), personality factors such as the Big Five (Trapmann et al., 2007; Ziegler et al., 2010), cognitive predictors such as IQ (Sternberg et al., 2001), and various other psycho-social factors such as parental education, identity, and perseverance (Ramey et al., 2018). Lastly, we need tools to measure the knowledge, skills, and competencies of students to ascertain if the system is functioning as intended (Blömeke et al., 2013; Coetzee, 2014). These various factors of student success only form a portion of a highly complex multidisciplinary literature that is of interest to academics, post-secondary institutions, and governments around the world.

Speaking within the Canadian context, the study of student success in Canadian post-secondary education has appeared in the Canadian Journal of Higher Education (CJHE) since at least the early 1970s. The CJHE placed a special issue call which encouraged historical analyses that examined specific research themes found within the publication throughout the last 50 years. Throughout its history, the CJHE has reported on original research within the field of higher education with a unique dedication to furthering our understanding of the
Canadian post-secondary landscape. This literature review explores how student success has been represented and discussed within this singular, but established, publication. This analysis presents the opportunity to view the history and evolution of the study of student success, concerns and solutions offered by scholars, while simultaneously noting research topics that may require further exploration in the future.

\section{Method and Conceptual Framework}

The current literature review assessed relevant publications in the CJHE related to student success from the journal's inception in 1971 until the most recent issue at the time of writing. A conceptual framework was needed to define student success, as it is clearly a complex and multifaceted term. Ideally, such a framework would also assist in the identification and categorization of relevant articles found in the CJHE. The influential work of Kuh et al. (2006) met this criteria, and the authors clearly articulate that "student success is defined as: academic achievement, engagement in educationally purposeful activities, satisfaction, acquisition of desired knowledge, skills and competencies, persistence, attainment of educational objectives, and post-college performance" (p. 7). As such, each of these component metrics formulate the definition of student success for this review and assist in the categorization of articles to present analyses.

The locating of studies to include within this analysis began with the June 28, 1971 volume 1(1) issue of the CJHE and continued until volume 50(2), 2020-the last issue published at the time of writing. A total of 1,408 published, peer-reviewed articles were located within this 50 -year period. The researcher located relevant publications by title and abstract review and then categorized the publications into one or multiple constructs of Kuh et al.'s (2006) definition. Seventy-one studies were initially found that fit the criteria; however, throughout the analysis some articles were removed upon further review. This removal was primarily due to lack of thematic fit within Kuh et al.'s (2006) framework. However, a limited number of studies (six) were included in the final count that did not fit the framework. These articles are presented in the discussion section, as the researcher deemed the topics of Aboriginal students' success and psychological/ psychosocial success factors relevant to the discussion despite not slotting into Kuh et al.'s framework. As a result of these considerations, 60 unique studies (Table 1) from 
Table 1

The Study of Student Success in the CJHE

\begin{tabular}{lr}
\hline Success Metrics & Count \\
\hline Post-college performance & 18 \\
Persistence & 9 \\
Academic achievement & 8 \\
Attainment of educational objectives & 5 \\
Satisfaction & 7 \\
Acquisition of desired knowledge, skills, and competencies & 6 \\
Engagement & 2 \\
Aboriginal student success & 3 \\
Psychological/psychosocial factors & 2 \\
\end{tabular}

the CJHE are included in this review and can be found categorically presented in the appendix.

\section{Post-College Performance}

To begin, and perhaps unsurprisingly, post-college performance was the measure of success found most represented in the CJHE. Post-college performance is defined as enrolment in graduate school/professional school, the desire to pursue lifelong learning, and employment (Kuh et al., 2006). The term post-college is somewhat of a misnomer, as it refers to both post-college and post-university performance and should be considered for the remainder of this article as referring to success after graduation from higher education in general.

Without a doubt, employment and labour market outcomes have been the focus of much of the scholarship on student success within the CJHE. Scholars since the 1970s have consistently warned of the employment issues related to graduates from specific disciplines, and the ever-changing landscape of the post-college employment sectors. Arguing that a university degree or college degree no longer meant guaranteed and stable employment in one's chosen field, these early scholars laid a foundation of research within the journal that was concerned with the labour market outcomes and return of investment of higher education (Beach, 1977; Ralston, 1978). Beach (1977) specifically cautioned readers of the "serious problem of over-education in Canada" ( $p$. $15)$ and that the boom of men and women in the workforce "simply outpaced the production of new jobs" (p. 7). Ralston (1978) also stated that educational expansion and rapid changes to the economy and occupational structure resulted in precarious post-graduation employment.

Such findings were troubling to scholars of the day, as they pointed to a possible future that further devalued a university or college degree and a mismatch between a credential and the labour market. Research that was conducted in the mid-1990s, but which reported data from the mid-1980s, unfortunately did not have better news for those concerned, as Redpath (1994) found over one-third of bachelor's degree graduates were underemployed two years after graduation. Redpath found that although employers stated there was a shortage of skilled scientists, " $45 \%$ of the Science graduates...were underemployed, $42 \%$ said their jobs were not related to their education and training, and $30 \%$ reported that their skills and abilities were not being utilized on the job" (p. 104). Those students with Arts degrees fared no better. Ten years later, Walters (2004) added significant evidence to the underemployment issue with data from Statistics Canada's 
National Graduates Survey $(n=43,040)$. Results from this study demonstrated that there were many graduates, especially those enrolled in liberal arts, who obtained employment not related to their education. Walters argued that there was "widespread mismatching of credentials in the labour market, leaving the talents of many educated people underutilized" (p. 116). Thus, unfortunately, many of Beach's (1977) concerns regarding an oversaturated market and an underemployed graduate landscape continued to be of concern to scholars some 25 years later.

Initial analysis of post-college performance studies identified a common theme of underemployment and the underutilization of graduates within society. Unsurprisingly, certain disciplines/fields of study have better employment attainment than those in other fields. This led to questions about the value of various degrees and further analysis revealed how this scholarship has been explored in the CJHE.

\section{The Value of a Degree}

Over the years, various scholars who published in the CJHE examined the career outcomes of college and university graduates delineated by field of study. Disciplines include sociology (Ralston, 1978), psychology (Rennie, 1981), political science (Archer, 1986), liberal arts versus applied programs (Adamuti-Trache et al., 2006), and the humanities (Fenesi \& Sana, 2015). Authors have also collected data from graduates of multiple disciplines and included comparisons of their labour outcomes within the same study (Finnie, 2001; Frank \& Walters, 2012; Walters, 2004). The liberal arts and humanities were often the focal point for concern among these studies, as authors have consistently reported on the unemployment and underemployment of graduates from these programs, which have long-term personal and societal implications.

In the early history of the CJHE, three studies were explicitly interested in the labour market outcomes of graduates who graduated from particular disciplines at specific institutions. All three studies conducted mail-out questionnaires to graduates with sample sizes ranging from $n=199$ to $n=325$. The sample population for these studies were sociology graduates at an undisclosed maritime university (Ralston, 1978), psychology graduates from York University (Rennie, 1981), and political science graduates from the University of Calgary (Archer, 1986). These authors all stressed a concern regarding the career paths of social science/humanities graduates and an explicit effort to track the outcomes of those individuals who chose to engage in a liberal arts education. A notable finding was that many graduates sought further education in graduate or professional schools in all three fields of study. These findings can be interpreted in a variety of ways depending upon one's world view. Kuh et al. (2006) include enrolment in professional/graduate school and lifelong learning as measures of post-college performance, which is housed under the mantle of student success. Therefore, utilizing this frame, these findings can be interpreted as positive outcomes as they would suggest students were incentivized to continue their education and explore the complexities of graduate and professional studies. However, a credentialist perspective (Collins, 1979) would argue that there is a significant mismatch between the liberal arts credential and what opportunities exist in one's field post-graduation.

The data from these initial studies seems to support this credentialist view to some degree as participants reported relatively positive employment options, albeit not necessarily in their field as defined by traditional means. These studies were not concerned with defining and measuring underemployment or overqualification; therefore, it is impossible to say if these phenomena were experienced by the samples captured. However, it can be inferred that graduates had to remain flexible and open to further education and alternative career prospects than perhaps the traditional goal of strictly working in one's field. As a result, some credence is given to the credentialist viewpoint by these early results. As these studies were conducted in the 1970s and 1980s, there is an obvious limit to the sample size collected as largescale computer-based data collection methods were not widely available to researchers. Interestingly, more recent studies continued to explore the concerns stated by this early scholarship in the CJHE.

It is evident that concerns regarding the employment outcomes of graduates from liberal arts-and more specifically, humanities-continued to be an issue of some importance to scholars throughout the history of the CJHE. A standout paper from the 1990s was Redpath's (1994) work which explored underemployment across numerous disciplines including amongst Arts graduates and continued to present the narrative that perhaps education was failing to prepare young graduates for the ever-changing labour market. Other work in this vein was limited during the 1990s, as other scholars tended to fo- 
cus on specific sub-populations such as university characteristics and various job-related success metrics for accounting graduates (Colarelli, 1991) and the retention of women in science (Donaldson \& Dixon, 1995). Many of these studies, similarly to the studies noted in the 1970s and 1980s, were limited in their broader applicability due to their use of smaller sample data often drawn from survey/questionnaire data conducted by the authors themselves. While these earlier studies are clearly still valuable, the turn of the millennium marked a distinct shift in the body of work on employment outcomes of graduates as scholars started to publish research that used broader scale data collected by provincial and federal agencies.

\section{Liberal Arts}

Early in the new millennium, Finnie (2001) was able to collect three waves of National Graduate Surveys (NGS) from 1982, 1986, and 1990, and interview participants two and five years post-graduation. Finnie reported on a range of post-graduation outcomes, such as employment levels, job-education skill matching, and earnings. Arts, humanities, other social sciences, and agricultural and biological science graduates were all found to be low in earnings, low in skill matching, and with high rates of unemployment. Based on these findings, the author noted a surprising finding that fine arts and humanities scored in the middle rankings of an approval rating index regarding one's education, suggesting that, at least to some fine arts and humanities graduates, satisfaction with one's education was measured in more than mere job preparation.

Finnie's work has twofold significance. Firstly, it marks the first publication in the CJHE that specifically analyzes labour market outcomes of Canadian post-secondary graduates delineated by discipline conducted on such a large scale. Finnie contributed large, stratified, random samples of more than 30,000 students per NGS collected from a time when most studies utilized paper-based survey data. Secondly, Finnie's work confirms many of the concerns noted in the works of Beach (1977), Rennie (1981), and Redpath (1994). These scholars, among others, raised numerous concerns regarding the value of a liberal arts or humanities degree, and Finnie's work seems to confirm that those graduates were at a significant disadvantage in terms of stable employment, but also in terms of job-education skill matching and in- come. Furthermore, Finnie's finding that agricultural and biological sciences were also at a significant disadvantage provides some confirmatory evidence to Redpath's (1994) findings to the underemployment and skill mismatch of science graduates. Finnie's work presented troubling statistics-that a large portion of graduates from numerous disciplines over almost an entire decade faced numerous challenges within the post-graduation job market. With vast changes to the labour market on the horizon due to innovations in the technology sector, one would expect these challenges to compound and remain unsolved if not explicitly addressed by all stakeholders involved.

The remainder of the studies located in the CJHE that specifically addressed the labour market value of various higher education disciplines drew data from either the NGS (Fenesi \& Sana, 2015; Frank \& Walters, 2012; Walters, 2004) or from a province specific graduate survey (Adamuti-Trache et al., 2006). Walters (2004), drawing from the NGS data of $1995(n=43,040)$, found a widespread mismatch between the education of liberal arts graduates and their placement in positions where they were not making use of their education. Walters argued that this finding suggests a large underutilization of the abilities of new graduates, particularly in the early years of their post-graduation careers. Further supporting Walters's (2004) finding, Adamuti-Trache et al. (2006) compared the market value of a liberal arts degree to an applied degree within the 1996 British Columbia context. Findings suggested that liberal arts graduates experienced a delayed integration and professional recognition in the labour market, whereas applied program graduates had an advantage in employment status and income. Of note, over time, these discrepancies were found to diminish; however, this was noted to be likely due to liberal arts graduates being more pragmatic with their education and labour market goals. Frank and Walters (2012) found similar results within the Ontario context, reporting that graduates from applied and technical fields fared better in terms of earnings than liberal arts graduates shortly after graduation. However, the authors reported a somewhat better outcome, as liberal arts graduates appeared to obtain higher remuneration when compared to graduates from non-university specific programs (i.e., community college). Lastly, reporting on the cross-Canada context and utilizing 2007 NGS data $(n=$ 39,588 ), Fenesi and Sana (2015) found that humanities 
graduates specifically were at a "significant disadvantage" (p. 394) when compared to almost all other major fields (i.e., STEM, business, social science, education). The authors argued that humanities programs provide generic skills not specific to a specific labour market. Therefore, graduates were more likely to be overqualified in terms of education and working in an unrelated field. Since humanities programs tend to have the highest of all enrolment rates in university, these findings raise significant concerns regarding the employability and return on investment for humanities graduates, as well as the societal value of the degree.

\section{Summary of Employment Outcomes}

This section focused on studies within the CJHE that examined employment and has produced some intriguing and consistent results throughout the almost 50-year analysis. Scholars since the 1970s have been voicing concerns and finding evidence of underemployment and indeed unemployment of graduates, most noticeably from liberal arts and humanities programs. As technology improved and researchers had better access to multi-institutional and multi-provincial data, these concerns were further confirmed by large-scale statistical testing. While one would expect a stratification among the disciplines regarding labour market outcomes, it is troublesome that many CJHE scholars have felt that the current hierarchy underutilizes the skills of graduates, which has broader implications for society. Kuh et al. (2006) note that the Institute for Higher Education Policy argues that both individuals and society as a whole benefit from each person who attends post-secondary education; however, findings from the Canadian context and the CJHE in particular suggest that we are underutilizing some graduates, which, in turn, may also stifle their post-college success. Findings also suggest that perhaps the system itself is underprepared to support the workplace skill development of underserved and underutilized graduates. Academics themselves also seem to disagree on how to develop such skills/competencies/attributes, or if they are even responsible for doing so (Kanuka \& Cowley, 2017). This ambiguity leaves affected students with the navigational challenge of directing their careers toward an uncertain labour market. Graduate school is an enticing option for many, as further investment in credentialism suggests a likely future career reward.

\section{The Outcomes of Graduate School}

A notable theme found in the above literature is that, due to the lack of employment incentives, many undergraduates chose to enroll in graduate school to boost their market value. However, despite the obvious questions regarding post-graduate school employment outcomes, almost no research was published in the CJHE prior to 2017 that sought insight into graduate student populations. Von Zur-Muehlen's (1978) study, which examined the growth, demand, and imbalance of $\mathrm{PhD}$ education in Canada, stands out as the notable exception prior to a surge of interest beginning in 2017. Von Zur-Muehlen's large report presented, among other things, a statistical outline of the PhD system in Canada at the time, enrolment patterns of both full-time and part-time students by field of study and provincial student loan data, the growth patterns of PhD programs by discipline, and finally, predictions for supply and demand of the remainder of the decade and into the 1980s. Von Zur-Muehlen's work was extensive and employed data from the "Highly Qualified Manpower Survey" (p. 51). Notably, the author found an oversupply of $\mathrm{PhD}$ graduates in the natural sciences, the humanities, and the social sciences, which was attributed to lack of university teaching positions available. This lack in positions was attributed to the reliance on "less than fully-trained personnel" (p. 91) during the university boom of the 1950s and 1960s, when PhD graduates were scarcer. Therefore, Von Zur-Muehlen cautioned that PhD graduates would have to pursue alternative careers outside the traditional academic route, which needed to be developed by universities, as well as government and industry.

Despite Von Zur-Muehlen's (1978) early warnings, issues of underemployment and an oversupply of PhD graduates has only recently been explored within the CJHE. Etmanski et al. (2017) explored this issue broadly across disciplines, while discipline-specific studies have been conducted on humanities (McAlpine \& Austin, 2018) and planning (Ross et al., 2018) graduates. Waite (2017) also contributed a significant amount of data and discussion regarding post-graduate wage premiums and the gender wage gap that adds needed nuance to the economic values attributed to specific degrees for men and women respectively. Etmanski et al. (2017) found that, regardless of field of study, only a small percentage of $\mathrm{PhD}$ graduates "were predicted to obtain full-time permanent positions in academia within three years of graduation" (p. 164). Despite the authors reporting that 
most doctoral graduates sought a $\mathrm{PhD}$ to become professors, these findings suggest that underemployment at the highest levels of education may be more prevalent, regardless of discipline of study. In addition, both discipline-specific studies (McAlpine \& Austin, 2018; Ross et al., 2018) found that, due to the lack of academic/ professorial opportunities, further program-specific career and professional development support is needed in order to prepare graduates for careers outside of the academy. Lastly, Waite (2017) offered somewhat positive encouragement toward post-graduate education as findings reported a distinct wage advantage for completing advanced education. However, graduates from the humanities experienced a much lower post-graduate wage premium, while for those in business, management, and public administration it was much higher. Interestingly, women were found to benefit more than men from a larger wage premium for completing post-graduate studies at both the masters and the doctoral level. A gender wage gap which favoured men was noted that was smaller at the master's level but not at the doctoral level. Despite the substantial gains of women toward educational attainment, the author noted that differences in hours worked and occupation continue to disadvantage women regarding the gender wage gap.

Despite the significant gap in research specifically addressing post-graduate employment outcomes, recent studies have highlighted similar and significant challenges that were noted in the 1970s. Underemployment of highly educated individuals continues to be of concern to scholars-reflecting a persistent theme found within the post-college literature within the CJHE. When measuring student success by including a metric of post-college performance, findings from the CJHE suggest that, despite high levels of credentialism, many graduates are perhaps still underutilized within Canadian society. With such a realization regarding the prospects of meaningful employment post-graduation, the persistence of students within higher education becomes even more challenging as the value of a degree is called into question.

\section{Persistence}

Persistence refers to whether a student continues toward completing their educational goal, which may take place across long periods of time and multiple institutions. It is a dynamic relationship between individuals and members of the institution and their own personal community (Kuh et al., 2006). There are numerous risk factors that can affect student persistence, such as being a single parent, working more than 30 hours a week, or being a first-generation student (Community College Survey of Student Engagement, 2005). Persistence is distinctly different from retention, as retention refers to the university/college organizational phenomenon (Reason, 2009), while educational persistence is a result of various personal factors and choices. This distinction is very important when looking at the 50-year history of the CJHE, as it was not until the late 1990s that scholarship began to distinguish between the two terms (Berger \& Lyon, 2005). As such, persistence and retention are often used interchangeably, even to this day; however, each is distinct and should not be used in this manner as they are decidedly different (Falcone, 2011). As a result, throughout data categorization for this article, numerous studies identified various factors affecting student persistence while studying student attrition and institutional retention. Therefore, these studies were included in analysis as they offered insight into various phenomena affecting student persistence within the Canadian higher education context.

Although the broader academic literature would not distinguish between retention and persistence for some time, Black (1972) challenged the concept of the university dropout. This early CJHE author suggested that dropping out may be just an interruption to a student's education and replaced by "real-life experience" (p. 36) for some period before they return to post-secondary to achieve their goals. This is an example of student persistence despite the loss to institutional retention rates. Black's theorization is an important initial distinction, as it begins a broader conversation about what dropping out really means. The exact causes that damage student persistence are explored much more in articles published later in the journal.

\section{Persistence Factors}

At the aggregate level, one may expect that the most likely group to withdraw from post-secondary education and perhaps not return are those who were enrolled in first year studies. This is confirmed by studies on student attrition and retention found within the CJHE (e.g., Johnson \& Buck, 1995; Madgett \& Bélanger, 2008) and 
in the broader literature itself (e.g., Pancer et al., 2000). One possible reason for the likelihood of first-year student withdrawal is that individuals are faced with a mismatch between their expectations of an institution or program and the realities of each. Authors within the CJHE have explored this hypothesis and have found that students reported "a poor fit between their characteristics and those of the institution" (Dietsche, 1990, p. 80) within the College of Applied Arts and Technology of Ontario context. This research also indicated that students must find their program intellectually engaging and rewarding-specifically toward future labour market success. Students who were unhappy with the program or curriculum content and were unable to ascertain educational or occupational goals (Stewart, 1990) were also found to withdraw within the health professional school context. As a result, students who had a difficult time integrating into the academic or social environment and who were not confident that their enrolment would achieve their goals were more likely to leave (Madgett \& Bélanger, 2008).

These studies speak to the psychological state of students and their views on the programs and higher education in general. Perceived employment options and their appeal to withdraw (Ungar, 1980), satisfaction with the program/school, goal commitment, and stress and fatigue (Johnson \& Buck, 1995) have all been identified as factors affecting student attrition or persistence. CJHE scholars also found that one's educational background and access to high-quality academic high school programs (Andres \& Krahn, 1999) or financial burdens due to educational costs (Madgett \& Bélanger, 2008) are also contributing factors to persistence. Furthermore, racial differences and inequality are also often seen as a significant factor; although, Grayson's (1995) extensive research suggested that, at least at York University in the middle 1990s, the first-year experience had "a considerable degree of racial equality in outcomes" (p. 106). Finally, a more recent study within the CJHE sought to further identify psychological characteristics that either support or impede students' success employing qualitative methods of content analysis (Stelnicki et al., 2015). The authors found that undergraduate students $(n=1,427)$ identified persistence as a major contributing factor to overall student success and goal achievement. This finding suggests that students within the sample were keenly aware of the necessity to dedicate themselves to their education and did not overly emphasize factors such as one's innate academic ability. The authors also found that stress, poor academic skills, and distraction were significant detractors of one's overall success in post-secondary, reconfirming similar results found by Johnson and Buck (1995).

The findings related to persistence present a consistent case that the academic university/college environment and fit with one's program and/or school are both paramount factors in a student's decision to withdraw. Furthermore, various employment opportunities, stress or fatigue, and one's educational and financial backgrounds can all play a significant role in student attrition or lack of persistence. Interestingly, students themselves also seem to understand the importance of persistence, suggesting that ability may not be the most sought-after trait. These findings may not be particularly shocking to some; however, they do represent the importance of transparency regarding the academic expectations of programs. Furthermore, providing clearly stated outcomes regarding the benefits of completing a specific program is likely highly beneficial for students, especially when considered in tandem with the labour market concerns noted in the previous section. While programs and institutions may be able to contribute to a positive and supportive environment to assist in student persistence, various studies within the CJHE focused on outside factors that affect persistence, many of which are outside of institutional control. Therefore, these findings suggest the continual importance of student support service professionals and other niche services such as financial advising and family support, as these options likely serve to decrease student attrition.

\section{The Remaining Components of Success}

As previously stated in the introduction of this article, post-college performance and persistence are the two constructs of student success identified by Kuh et al. (2006) that are the most represented with the history of the CJHE. However, as this study sought to locate and categorize the entirety of each construct, where possible, this section briefly summarizes the findings of the remaining measures of student success. Omitted from this section is discussion of engagement in educationally purposeful activities, as sufficient research could not be located for this construct. 


\section{Academic Achievement}

Academic achievement, measured almost exclusively by GPA, is the next most represented construct found with the CJHE. It is difficult to discern a substantial theme from the studies collected, as academic achievement is utilized in numerous ways. Some authors employed GPA as a predictor variable of future post-secondary or career success (e.g., Allan et al., 1983; Ayers, 1980; Nevitte et al. 1988), while others were instead interested in other factors' influence on academic achievement. Academic achievement in these studies was classified as an outcome variable where racialized status (Grayson, 1995), student residency (Grayson, 1997), gifted student status (Grayson, 2001), English language learner status (Roessingh \& Douglas, 2012), and resiliency and personality variables (Wilson et al., 2019) were explored as contributing (or not) to academic achievement. Due to the wide range of interests of scholars, these studies present a mix of positive and negative correlations; however, due to the limited nature of Canadian-specific higher education research, the specificities presented within these studies offer valuable insights.

\section{Attainment of Educational Objectives}

Attainment of educational objectives is the follow-up construct in that there are fewer studies that directly explore this topic than those on academic achievement. Many scholars have considered degree attainment as the definitive measure of student success (Kuh et al., 2006); however, while degree attainment may be a primary goal for most students within higher education, it is certainly not the only possible educational objective that they may have. As a result, the classification of studies pertaining to attainment of educational objectives was particularly challenging even with a flexible classification scheme. Thus, relatively few studies in the CJHE addressed this measure in comparison with previous success components.

Early work by Dennison et al. (1982a, 1982b) provided an interesting glimpse into the degree completion and academic behaviour/goals of transfer students within the context of British Columbia and the importance of the college sector in supporting students' professional and personal goals. Interestingly, 20 years later, Andres and Looker (2001) examined the educational attainment and expectations of youth in Nova Scotia and British Columbia from rural, urban/rural, and metropolitan settings.
The authors found that although Nova Scotia youth were less likely to participate in post-secondary education compared to B.C. youth, British Columbia had fewer university graduates among the urban/rural population than Nova Scotia. This finding suggested high participation rates among urban/rural youth in B.C. higher education in general when compared to Nova Scotia, but lower completion rates in university. Such a finding denotes barriers in the B.C. transfer system from college to university and issues with persistence and retention. These studies suggest that there are structural components within Canadian higher education that either assist or hinder attainment. Outside of post-secondary system design and internal barriers, Christofides et al. (2012) found numerous external factors that affect post-secondary outcomes such as parental support, peer support, and the development of aspirations through the high school years. The authors specifically suggest that counselling for parents on the importance of higher education while their children are in high school can significantly improve post-secondary attainment. This finding, similar to system level barriers, is often outside of the control of the student themselves. Etcheverry et al. (1993) explored what is grounded firmly within students' realm of control: the relationship between student time use and educational attainment. The authors found that students with more credit hours and who were, therefore, more challenged and committed to their programs, had "ultimately higher grades and educational expectations" (p. 15). Furthermore, paid employment was found to have no effect, while time spent attending class was found to have little effect on educational attainment. These findings suggest that students adjust their time commitments such as work and credit hours in order to continually pursue their educational objectives without sacrificing grades or educational expectations. Thus, the authors argue that other roles have little to no impact on educational attainment.

Findings located within these limited number of studies do suggest that factors both within the student's control (e.g., if they go to class or not), and outside the student's control (e.g., if they need to work, if they have good parental support, etc.) play varying degrees of significance to educational attainment, and not always in the way that is expected. The higher education system itself obviously has a significant role in supporting educational attainment, but the nuances of the various pro- 
vincial systems in comparison with each other provides significant avenues for research.

\section{Satisfaction}

Perhaps a more difficult measure to assess than the previous components of this section is the degree to which students are comfortable and affirmed in their learning environment, and satisfied with their learning experience (Kuh et al., 2006). Academic and institutional quality, achievement of desired outcomes, willingness to continue their education, and likely many other factors can influence students' level of satisfaction. Therefore, studies that explored satisfaction within the CJHE are broad in their approach to the subject, with various avenues taken by authors that cover a wide range of topics.

A generalized interest in the undergraduate student experience marks some of the limited work on satisfaction found within the CJHE. Holdaway and Kelloway (1987) explored the perceptions and experiences of students, and regarding satisfaction found that female students were found to show higher levels of interest, enjoyment, and satisfaction than male students; however, no concrete rationale was provided to explain this finding. Gomme et al. (1993) also sought to explore the undergraduate experience, and among many other findings not related to satisfaction, found that undergraduate students were dissatisfied with a lack of opportunity to evaluate the teaching of their professors and teaching assistants. Such a finding is noteworthy, as it marks a distinctly different landscape regarding student participation in the teaching process than the one currently integrated into the higher education system. Regarding faculty performance and its relation to student satisfaction, Bravo et al. (2007) developed a tool to monitor health science graduate students' perceptions of the quality of their supervision, which suggests continued interest in faculty accountability at the graduate level and its role in student satisfaction.

International/non-European-origin student satisfaction was of interest to scholars through the years, as students were surveyed regarding satisfaction with university campus life and services (Zelmer \& Johnson, 1988) and college support structures in relation to meeting students' needs (Kilbride \& D'Arcangelo, 2002). While the former study reported relatively positive satisfaction results from its sample $(n=28)$, the latter study $(n=146)$ highlighted numerous areas where the college could markedly improve in its effectiveness in helping students. While Kilbride and D'Arcangelo (2002) did not explicitly study student satisfaction in their examination of student needs, one only needs to infer that an increase in student assistance would improve student satisfaction with a given institution structure. Building in some regard on his earlier work within the CJHE (Grayson, 2004), Grayson's (2007) work explored students' assessments $(n=513)$ of (among other concepts like professor performance) academic program satisfaction over a four-year period and attempted to "determine the impact of ethno-racial origin" (p. 75). Comparing European-origin students to Chinese-origin students, Grayson found that while GPA and professor performance contributed to program satisfaction for European-origin students, personality characteristics predisposed these identified students to evaluate the university environment more positively. Chinese-origin students, conversely, were found to report that the greatest predictor of program satisfaction was equal treatment of visible minority students. Such a finding, the author noted, suggested that perhaps Chinese-origin students faced "an inability to experience one-self and the environment as structured, predictable, and explicable." (p. 76). Numerous other findings in this study, and in Grayson's previous work (2004), are noteworthy, and should be explored further by those interested in satisfaction and/or equal treatment of student populations.

Studies directly related to satisfaction found within the CJHE are limited; however, the ones located suggest the importance of program support and an environment conducive to a diverse and international student body. Furthermore, instructional quality likely continues to play a significant role in student satisfaction, and the student voice has been paramount to this development. Perhaps the most cogent example of this is the Teaching Excellence Framework (TEF) implemented by the U.K. Quality Assurance Agency (QAA).

\section{Acquisition of Desired Knowledge, Skills, and Competencies}

Benefits of a university or college degree come in many forms. From post-college outcomes noted previously, to the attainment of educational goals set by individuals, there are many reasons why one may wish to pursue higher education. Perhaps the simplest to conceptualize 
and likely the hardest to tangibly measure are the desires to increase one's knowledge and/or skillset, or develop various competencies. The empirical studies that discuss this component of student success found within the CJHE are limited. Early work by Church and Gillingham (1988) explored undergraduate student educational goals and found increasing knowledge and understanding of an academic field to be the most important factor for students, with skill development factors and career opportunities also being highly meaningful. Evers and Gilbert (1991) took skill development a step further and surveyed students on their background characteristics and then contacted students with four-over-time surveys to assess their experiences, learning, and knowledge acquisition within university. The authors reported that students generally rated themselves high on most dimensions such as problem-solving skills and time management skills, but lower on quantitative/mathematical skills, supervisory skills, communication skills, risk-taking, leadership, and creativity/innovation (p. 74). The authors emphasized that universities need to stress communication skill development, creativity, and leadership, and avoid rote, petty conformity, and the narrowing of competencies. While a wide range of studies within the journal could be included here as they include sections on skill, knowledge, and/or competency development (or underdevelopment) within higher education specifically (e.g., Etcheverry et al., 1993; Stelnicki et al., 2015), there is a lack of studies focusing specifically on these outcomes. Hurst et al. (2013) contribute a mixed-methods study to begin to fill this deficiency by focusing on online learning and professional skill development. The authors reported numerous positive outcomes perceived by participants who engaged in three online workshops aimed to improve academic writing, career planning, and personal management strategies. Students were found to report benefits to attending the workshops, although a clear limitation is that these results were self-reported and do not necessarily reflect tangible increases to ability or knowledge in one of the various workshop topics.

Perhaps due to criticisms of generic skills and their insufficient nature in the 21st century landscape (Barnett, 2006), or perhaps a general lack of meaningful data, studies within the CJHE that specifically addressed the acquisition of knowledge, skills, and competencies were found to be very limited. Kanuka and Cowley (2017) noted that some Canadian universities have adopted an at- tribute model to mark distinctions between graduates of their programs when compared to others, and that these attributes are markedly different than skills or competencies. Such an observation may suggest future interest in expanding our definitions of knowledge, skills, and outcomes to a more institutional/program-specific model; however, until such a shift occurs, there is continual interest in measurement of this component found outside of the CJHE context (e.g., Lenarcic Biss \& Pichette, 2018; Weingarten et al., 2019).

\section{Discussion and Directions for Research}

Findings from this analysis suggest that there are disproportionate interests in specific components of student success when compared to other measures. The most glaring concern from the journal's inception up to the modern day is centred on post-college performance, employability, and, more specifically, the underemployment of graduates from the arts and humanities. These issues continue to be extremely relevant as such graduates often lack specialized skills (Telling, 2018) and face a considerably more difficult transition from school to work (Drewes \& Giles, 2001). Therefore, crucial research is needed on the knowledge, skills, competencies, and attributes of students within these disciplines, how these skills transfer to the labour market (or do not transfer), as well as development and insight into how faculty and post-secondary programs themselves are supporting students in post-college success other than simply suggesting graduate school enrolment.

Regarding graduate school, there is a significant gap in publications dedicated to the study of post-graduate education employment outcomes within the CJHE. This is shocking due the massive expansion of $\mathrm{PhD}$ programs across the sector in recent decades and the considerable investment in research found within Canadian institutions. Recent studies within the journal (e.g., McAlpine \& Austin, 2018; Ross et al., 2018) suggest that $\mathrm{PhD}$ graduates are facing a stark landscape of employment opportunities within academia, and therefore must look elsewhere for meaningful work that utilizes their advanced skillset. This view is corroborated by a recent and extensive report published by the Council of Canadian Academics (CAA) on labour market transitions of $\mathrm{PhD}$ graduates. Among many other notable findings that 
should be viewed in detail for those interested in this topic, the CAA expert panel found that Canadian PhD graduates face an increase in competition due to more $\mathrm{PhD}$ graduates competing for limited positions, a decline in professorial positions compared to previous decades despite an increase in $\mathrm{PhD}$ graduates and enrolment in higher education in general, and considerable challenges and underutilization within the non-academic labour force (Council of Canadian Academies, 2021). Despite these considerable issues, the authors note "the basic core structure of $\mathrm{PhD}$ programs in Canada has remained relatively constant" (p. xvii). This failure to adapt to current labour market trends is noted within the CJHE literature, and institutions, faculties, and supervisors must all support and even train students to possibly explore career alternatives outside academia. There is a dearth of research within the CJHE on exactly how this will be done, or results of planned intervention. Therefore, research that explores graduate students' use of institutional career centres, the outcomes of discipline-specific career workshops, further insight into graduate program curriculum that is designed to support (or not) labour market transitions, and insight into adaptations within graduate programs to support non-academic career success would all be of benefit to the CJHE and the broader field.

Persistence data are largely lacking as well, most likely due to the issues of tracking large samples of students once they leave one institution and perhaps enter another later in life. While attrition rates are certainly well-documented, the persistence of students within the sector itself could be explored much further by future research. Unfortunately for statistically driven researchers, such a task as tracking students across institutional or provincial lines presents a unique and almost insurmountable challenge. However, The Higher Education Quality Council of Ontario (HEQCO) has suggested the use of the Ontario Education Number "to track students across time and programs, and between institutions" (Kaufman et al., 2018, p. 43). Such an approach may offer unprecedented analysis advantages in understanding how students' educational journeys unfold and greatly further our understanding of persistence within the Canadian post-secondary context.

While the remainder of the constructs of student success, such as satisfaction and attainment of educational objectives, are significantly less represented in the CJHE literature than post-college performance or persistence, this offers contemporary researchers an avenue to explore. Attainment of educational objectives is extremely difficult to measure, as what exactly constitutes an objective is difficult to ascertain uniformly. This is further complicated by the differences in the higher education sector found within various provinces. However, as Ontario continues to expand its transfer system between college and university, interesting comparisons regarding attainment could be drawn between a relatively new system like the one found in Ontario and the much more established and fully articulated college transfer system found in British Columbia, for example. Also, there is a constant need for reassessment of student satisfaction in conjunction with exploration of their educational objectives. Perspectives on student perceptions of, and satisfaction with, the effectiveness of their education in fulfilling their goals-which may be educational, personal, or professional in nature-may contribute to addressing some of the issues in other constructs of success, such as post-college performance and persistence.

Studies were also found that spoke to the general success of specific demographics of students who would not benefit from inclusion into a single construct of success due to the multi-faceted nature of supporting students within these classifications. Nowhere was this more apparent than studies that focused on supporting the success of Aboriginal students (e.g., Gallop \& Bastien, 2016; Hampton \& Roy, 2005; Pidgeon et al., 2014). A consistent theme from this body of work is the role that institutions, faculty, and student peers have in creating a positive learning environment with supportive relationships that foster a sense of belonging in higher education for Aboriginal students. Culturally relevant processes and belonging (Pidgeon et al., 2014), supportive institutional/instructional spaces (Gallop \& Bastien, 2016), and positive professor-student relationships, perhaps informed by Aboriginal pedagogy (Hampton \& Roy, 2005), are just some of the findings/recommendations offered by these scholars that may support Aboriginal student success in higher education. These valuable insights-as well as findings found within other studies that focused on other unique subpopulations (e.g., international students) could be an avenue for a future literature review and expanded research.

Also, an area that could benefit from further research and that is underrepresented within the CJHE is insights 
into the various psychological and psycho-social factors that affect student success (Lisnyj et al., 2020; Ramey et al., 2018; Wasylkiw et al., 2020). Such studies present a unique and quantitative perspective into the complexities of some predictive factors of student success. These authors examined numerous factors that may predict student success, such as perseverance and maternal education (Ramey et al., 2018), contributors to anxiety (Lisnyj et al., 2020), and self-esteem, self-compassion, self-efficacy, and participants' mindsets of their own abilities (Wasylkiw et al., 2020). These studies are all newly published and further studies within the field of the predictive validity of psychological outcomes in academic success would likely be a welcome addition to the student success literature within the CJHE and the broader field of higher education.

Regarding study design, surveys designed and conducted by a single researcher or small research team were found throughout the CJHE as a common data collection technique. A clear limitation of this type of data collection is that often researchers are unable to collect multi-institutional or multi-provincial data, which often limits sample size. Acknowledging the complexities of proper survey design and the logistical difficulties of implementation, this lack of large comparison data makes findings less applicable to the wider Canadian higher education audience. Studies that drew from the National Graduate Survey (NGS) (e.g., Fenesi \& Sana, 2015; Frank \& Walters, 2012; Walters, 2004) or similar big data hubs provided a much more applicable lens through which to view student success due to their ability to speak to the wider higher education context. As a result, future research utilizing the NGS, The Youth in Transition Survey (YITS), or Statistics Canada data would likely be of great interest and importance to researchers who seek to understand the factors of success within the system-wide context.

At the qualitative level, research that explores how faculty members do or do not design curriculum and programs to meet post-college/university performance metrics such as employment outcomes could be conducted within particularly contentious disciplines such as the humanities. Insight into the philosophies and guiding principles of program designers and individual faculty mentors regarding their role in preparing students for post-graduate success outside the academy could provide valuable insights into the development and evolu- tion of such disciplines. These are just some avenues by which future researchers may choose to explore student success in higher education in Canada.

\section{Limitations}

There are a few noteworthy limitations of both this study and the data itself. One of the limitations of a qualitative literature review such as this is the subjectivity in the selection of sources. Due to the sheer number of studies reviewed and the criteria hinging upon title and abstract review, the inclusion of studies in this analysis is subjective despite the attempts of the researcher to include all relevant studies; therefore, some applicable studies found in the CJHE may not be represented. A limitation found within the CJHE was a lack of research on engagement in educationally purposeful activities. This was also a difficult construct to identify. Often measured by attendance in coursework (Beran \& Violato, 2009) or engagement with a specific pedagogical technique (Summerlee \& Murray, 2010), the CJHE presented very limited studies on engagement. Therefore, it was impossible to draw any meaningful conclusions in a dedicated section. York et al. (2015), in their literature review of the usage of Kuh et al.'s (2006) conceptualization of student success, removed engagement in educationally purposeful activities from analysis. Their rationale was that since academic success is an outcome, it follows that each construct should also be an outcome in which engagement in educationally purposeful activities is not, as it falls into the experience category. Therefore, the removal of this component measure was not a significant loss based on this sound rationale.

Regarding article selection and categorization, categorizing studies into a single component measure of academic success was done in order to present themes across time that may be useful to readers and to spark new lines of inquiry; however, many of the studies noted above fall into multiple categories. Therefore, it was the opinion of the researcher which findings fit into the best component measure of student success, but many articles could be categorized into multiple constructs of success (e.g., Andres \& Krahn, 1999; Etcheverry et al., 1993; Grayson, 1995; Ramey et al., 2018). 


\section{Conclusion}

The analysis presented in this article has found that student success within higher education has been of concern to a specific subset of scholars since the inception of the CJHE 50 years ago. The number of studies is modest when compared to the publication history of the journal, suggesting that the study of student success may be a somewhat small subfield within Canadian higher education research and certainly such within the CJHE. Despite this relatively small pool of articles, scholars have contributed research in many component measures of student success such as: post-college performance, persistence, academic achievement, attainment of educational objectives, student satisfaction, and the acquisition of knowledge, skills, and competencies. Findings suggest that many of the concerns of early CJHE scholars are still relevant to our contemporary landscape, such as the underemployment of graduates, concerns regarding the employment and utilization of PhD graduates, attrition factors, student goal attainment, and the measurement of skills or competencies gained by graduates. As the CJHE begins the climb to its centenary, current and future researchers have many avenues to explore, as the study of student success is an inexhaustibly complex construct while being continually relevant throughout the evolution of higher education.

\section{References}

Adamuti-Trache, M., Hawkey, C., Schuetze, H. G., \& Glickman, V. (2006). The labour market value of liberal arts and applied education programs: Evidence from British Columbia. Canadian Journal of Higher Education, 36(2), 49-74. https://doi.org/10.47678/ cihe.v36i2.183539

Allan, L. G., Darling, A. L., Hughes, R. C., \& Rosenfeld, J. M. (1983). An examination of performance of first year students at an Ontario university: An admission perspective. Canadian Journal of Higher Education, 13(3), 37-54. https://doi.org/10.47678/ cjhe.v13i3.182906

Andres, L., \& Krahn, H. (1999). Youth pathways in articulated postsecondary systems: Enrolment and completion patterns of urban young women and men. Canadian Journal of Higher Education, 29, 47-82. https://doi.org/10.47678/cjhe.v29i1.188469
Andres, L., \& Looker, E. D. (2001). Rurality and capital: Educational expectations and attainments of rural, urban/rural and metropolitan youth. Canadian Journal of Higher Education, 31(2), 1-45. https:/l doi.org/10.47678/cjhe.v31i2.183387

Archer, K. (1986). Political science BA graduates from the University of Calgary: Education and career paths. Canadian Journal of Higher Education, 16(3), 65-76. https://doi.org/10.47678/cjhe. v16i3.188395

Ayers, J. D. (1980). Relationship of first-year university grades of non-high school graduates with the tests of general education development. Canadian Journal of Higher Education, 10(1), 75-82. https:/l doi.org/10.47678/cjhe.v10i1.182809

Barnett, R. (2006). Graduate attributes in an age of uncertainty. In P. Hager \& S. Holland (Eds.), Graduate attributes, learning and employability (pp. 49-65). Springer.

Beach, H. D. (1977). Higher education and student employment needs. Canadian Journal of Higher Education, 7(3), 1-22. https://doi.org/10.47678/ cjhe.v7i3.182732

Beran, T., \& Violato, C. (2009). Student ratings of teaching effectiveness: Student engagement and course characteristics. Canadian Journal of Higher Education, 39(1), 1-13. https://doi.org/10.47678/ cjhe.v39i1.491

Berger, J. B., \& Lyon, S. C. (2005). Past to present: A historical look at retention. In A. Seidman (Ed.), College student retention: Formula for student success. ACE/Praege.

Black, D. B. (1972). Farewell, drop-out: Hello, drop-in. Canadian Journal of Higher Education, 2(1), 31-37. https://doi.org/10.47678/cihe.v2i1.182550

Blömeke, S., Zlatkin-Troitschanskaia, O., Kuhn, C., \& Fege, J. (2013). Modeling and measuring competencies in higher education. In S. Blomeke, 0 . Zlatkin-Troitschanskaia, C. Kuhn, \& J. Fege (Eds.), Modeling and measuring competencies in higher education (pp. 1-10). Sensepublishers.

Bravo, G., Saint-Mleux, J., \& Dubois, M. F. (2007). Health sciences graduate students' perceptions 
of the quality of their supervision: A measurement scale. Canadian Journal of Higher Education, 37(2), 69-88. https://doi.org/10.47678/cjhe. v37i2.541

Christofides, L. N., Hoy, M., Milla, J., \& Stengos, T. (2012). Grades, aspirations and post-secondary education outcomes. Canadian Journal of Higher Education, 45(1), 48-82. https://doi.org/10.47678/ cjhe.v45i1.184203

Church, J. H., \& Gillingham, D. W. (1988). Benefit segments for full-time undergraduate students. $\mathrm{Ca}$ nadian Journal of Higher Education, 18(2), 55-73. https://doi.org/10.47678/cjhe.v18i2.183037

Coetzee, M. (2014). Measuring student graduateness: Reliability and construct validity of the graduate skills and attributes scale. Higher Education Research \& Development, 33(5), 887-902. https:/l www.tandfonline.com/doi/pdf/10.1080/07294360.20 14.890572?needAccess=true

Colarelli, S. M. (1991). Relationships between university characteristics and early job outcomes of accountants. Canadian Journal of Higher Education, 21(3), 24-46. https://doi.org/10.47678/cjhe. v21i3.183109

Collins, R. (1979). The credential society. Academic Press.

Community College Survey of Student Engagement. (2005). Engaging students, challenging the odds: 2005 findings.

Council of Canadian Academies. (2021). Degrees of Success: The expert panel on the labour market transition of PhD graduates, council of Canadian academies. https://cca-reports.ca/wp-content/ uploads/2021/01/Degrees-of-Success FullReport EN.pdf

Dennison, J. D., Forrester, G. C., \& Jones, G. (1982a). Degree completion at British Columbia's universities. Canadian Journal of Higher Education, 12(2), 43-57. https://doi.org/10.47678/cjhe.v12i2.182855

Dennison, J. D., Forrester, G. C., \& Jones, G. (1982b). A study of students from academic programs in British Columbia's community colleges. Canadian Journal of Higher Education, 12(1), 29-41. https:/l doi.org/10.47678/cjhe.v12i1.182843

Dietsche, P. H. (1990). Freshman attrition in a college of applied arts and technology of Ontario. Canadian Journal of Higher Education, 20(3), 65-84. https:/l doi.org/10.47678/cjhe.v20i3.183086

Donaldson, E. L., \& Dixon, E. A. (1995). Retaining women students in science involves more than course selection. Canadian Journal of Higher Education, 25(2), 29-51. https://doi.org/10.47678/cihe. v25i2.183214

Dooley, M. D., Payne, A. A., \& Robb, A. L. (2012). Persistence and academic success in university. Canadian Public Policy, 38(3), 315-339. https:/l www.jstor.org/stable/41756297

Drewes, T., \& Giles, P. (2001). Liberal arts degrees and the labour market. Perspectives on Labour and Income, 13(3), 27-33. https://search.proquest.com/ docview/213991187?pq-origsite=gscholar\&fromopenview=true

Etcheverry, E. J., Clifton, R. A., \& Roberts, L. W. (1993). Time use and educational attainment: A study of undergraduate students. Canadian Journal of Higher Education, 23(3), 1-17. https://doi.org/10.47678/ cjhe.v23i3.183169

Etmanski, B., Walters, D., \& Zarifa, D. (2017). Not what I expected: Early career prospects of doctoral graduates in academia. Canadian Journal of Higher Education, 47(3), 152-169. https://doi.org/10.47678/ cjhe.v47i3.187784

Evers, F. T., \& Gilbert, S. N. (1991). Outcomes assessment: How much value does university education add? Canadian Journal of Higher Education, 21(2), 53-76. https://doi.org/10.47678/cjhe.v21i2.183101

Falcone, T. M. (2011, November 16-19). Toward a new model of student persistence in higher education [Paper presentation]. Annual meeting of the Association for the Study of Higher Education, Charlotte, NC, United States. https://files.eric.ed.gov/fulltext/ ED530661.pdf

Fenesi, B., \& Sana, F. (2015). What is your degree worth? The relationship between post-secondary programs and employment outcomes. Canadian Journal of Higher Education, 45(4), 383-399. 
https://doi.org/10.47678/cjhe.v45i4.183604

Finnie, R. (2001). Fields of plenty, fields of lean: The early labour market outcomes of Canadian university graduates by discipline. Canadian Journal of Higher Education, 31(1), 141-76. https://doi. org/10.47678/cjhe.v31i1.183381

Frank, K., \& Walters, D. (2012). Exploring the alignment between post-secondary education programs and earnings: An examination of 2005 Ontario graduates. Canadian Journal of Higher Education, 42(3), 93-115. https://doi.org/10.47678/cjhe.v42i3.1866

Frenette, M. (2014). An investment of a lifetime? The long-term labour market premiums associated with a postsecondary education (No. 2014359e). Statistics Canada, Analytical Studies Branch. https://www150.statcan.gc.ca/n1/ pub/11f0019m/11f0019m2014359-eng.htm

Gallop, C. J., \& Bastien, N. (2016). Supporting success: Aboriginal students in higher education. Canadian Journal of Higher Education, 46(2), 206--224. https://doi.org/10.47678/cjhe.v46i2.184772

Gomme, I. M., Hall, M. P., \& Murphy, T. J. (1993). In the shadow of the tower: The view of the undergraduate experience. Canadian Journal of Higher Education, 23(3), 18-35. https://doi.org/10.47678/ cjhe.v23i3.183170

Grayson, J. P. (1995). Does race matter? Outcomes of the first-year experience in a Canadian university. Canadian Journal of Higher Education, 25(2), 79-109. https://doi.org/10.47678/cjhe.v25i2.183216

Grayson, J. P. (1997). Place of residence, student involvement, and first year marks. Canadian Journal of Higher Education, 27(1), 1-23. https://doi. org/10.47678/cjhe.v27i1.183293

Grayson, J. P. (2001). The performance of "gifted" high school students in university. Canadian Journal of Higher Education, 31(1), 121-39. https://doi. org/10.47678/cihe.v31i1.183380

Grayson, J. P. (2004). The relationship between grades and academic program satisfaction over four years of study. Canadian Journal of Higher Education, 34(2), 1-34. https://doi.org/10.47678/cjhe. v34i2.183455
Grayson, J. P. (2007). Unequal treatment and program satisfaction among students of European and Chinese origin. Canadian Journal of Higher Education, 37(3), 51-85. https://doi.org/10.47678/cjhe. v37i3.530

Hampton, M., \& Roy, J. (2002). Strategies for facilitating success of First Nations students. Canadian Journal of Higher Education, 32(3), 1-28. https:// doi.org/10.47678/cjhe.v32i3.183417

Holdaway, E. A., \& Kelloway, K. R. (1987). First year at university: Perceptions and experiences of students. Canadian Journal of Higher Education, 17(1), 47-63. https://doi.org/10.47678/cjhe. v17i1.183008

Hurst, D., Cleveland-Innes, M., Hawranik, P., \& Gauvreau, S. (2013). Online graduate student identity and professional skills development. Canadian Journal of Higher Education, 43(3), 36-55. https:/l doi.org/10.47678/cjhe.v43i3.184674

Johnson, G. M., \& Buck, G. H. (1995). Students' personal and academic attributions of university withdrawal. Canadian Journal of Higher Education, 25(2), 53-77. https://doi.org/10.47678/cihe.v25i2.183215

Kaufman, A., Jonker, L., \& Hicks, M. (2018). Differentiation within the Ontario college system: Options and opportunities. Higher Education Quality Council of Ontario. https://heqco.ca/wp-content/ uploads/2020/02/College-Differentiation ENGLISH. pdf

Kanuka, H., \& Cowley, S. (2017). Graduand student attributes: A Canadian case. Canadian Journal of Higher Education, 47(1), 61-79. https://doi. org/10.47678/cjhe.v47i1.186485

Kilbride, K. M., \& D'Arcangelo, L. (2002). Meeting immigrant community college students' needs on one greater Toronto area college campus. Canadian Journal of Higher Education, 32(2), 1-26. https:/l doi.org/10.47678/cjhe.v32i2.183409

Kuh, G. D., Kinzie, J. L., Buckley, J. A., Bridges, B. K., \& Hayek, J. C. (2006). What matters to student success: A review of the literature (Vol. 8). National Postsecondary Education Cooperative. https://nces. ed.gov/npec/pdf/kuh team report.pdf 
Lenarcic Biss, D., \& Pichette, J. (2018). Minding the gap? Ontario postsecondary students' perceptions on the state of their skills. Higher Education Quality Council of Ontario. https://heqco.ca/wp-content/ uploads/2020/02/Formatted -Student-Skills-Survey FINAL.pdf

Lisnyj, K. T., Russell, R., \& Papadopoulos, A. (2020). Risk and protective factors for anxiety impacting academic performance in post-secondary students. Canadian Journal of Higher Education, 50(2), 71-88. https://doi.org/10.47678/cihe.v50i2.188715

Madgett, P. J., \& Bélanger, C. H. (2008). First university experience and student retention factors. Canadian Journal of Higher Education, 38(3), 77-96. https:ll doi.org/10.47678/cjhe.v38i3.503

McAlpine, L., \& Austin, N. (2018). Humanities PhD graduates: Desperately seeking careers? Canadian Journal of Higher Education, 48(2), 1-19. https:/l doi.org/10.47678/cjhe.v48i2.188157

Michalski, J. H., Cunningham, T., \& Henry, J. (2017). The diversity challenge for higher education in Canada: The prospects and challenges of increased access and student success. Humboldt Journal of Social Relations, 39, 66-89. https://www. jstor.org/stable/ 90007872 ? seq=1\&cid=pdf-reference\#treferences tab contents

Mueller, R. (2008). Access and persistence of students from low-income backgrounds in Canadian postsecondary education: A review of the literature. SSRN. https://papers.ssrn.com/sol3/papers.cfm?abstract id $=2256110$

Nevitte, N., Gibbins, R., \& Codding, P. W. (1988). The career goals of female science students in Canada. Canadian Journal of Higher Education, 18(1), 31-48. https://doi.org/10.47678/cjhe.v18i1.183028

Pancer, S. M., Hunsberger, B., Pratt, M. W., \& Alisat, S. (2000). Cognitive complexity of expectations and adjustment to university in the first year. Journal of Adolescent Research, 15, 38-57. https://doi. org/10.1177/0743558400151003

Pascarella, E. T., \& Terenzini, P. T. (2005). How college affects students: $A$ third decade of research. Jossey-Bass.
Pidgeon, M., Archibald, J. A., \& Hawkey, C. (2014). Relationships matter: Supporting Aboriginal graduate students in British Columbia, Canada. Canadian Journal of Higher Education, 44(1), 1-21. https:ll doi.org/10.47678/cjhe.v44i1.2311

Ralston, H. (1978). The uses of a bachelor's degree in sociology: Careers of recent graduates of a maritime university. Canadian Journal of Higher Education, 8(3), 47-66. https://doi.org/10.47678/ cjhe.v8i3.182776

Ramey, H. L., Lawford, H. L., Chalmers, H., \& Lakman, Y. (2018). Predictors of student success in Canadian polytechnics and CEGEPS. Canadian Journal of Higher Education, 48(2), 74-91. https://doi. org/10.47678/cjhe.v48i2.188110

Reason, R. D. (2009). An examination of persistence research through the lens of a comprehensive conceptual framework. Journal of College Student Development, 50(6), 659-682. https://doi.org/10.1353/ csd.0.0098

Redpath, L. (1994). Education-job mismatch among Canadian university graduates: Implications for employers and educators. Canadian Journal of Higher Education, 24(2), 89-114. https://doi.org/10.47678/ cjhe.v24i2.188441

Rennie, D. L. (1981). Survey of York University 1976-78 bachelor's degree graduates in psychology located in greater Toronto. Canadian Journal of Higher Education, 11(1), 45-57. https://doi.org/10.47678/ cjhe.v11i1.182828

Roessingh, H., \& Douglas, S. R. (2012). Educational outcomes of English language learners at university. Canadian Journal of Higher Education, 42(1), 80-97. https://doi.org/10.47678/cjhe.v42i1.182449

Ross, T., Mah, J., Biggar, J., Zwick, A., \& Modlinska, E. (2018). Student needs, employment realities, and PhD program design in Canada: The case of planning PhD programs. Canadian Journal of Higher Education, 48(3), 82-97. https://doi.org/10.47678/ cjhe.v48i3.188161

Stelnicki, A. M., Nordstokke, D. W., \& Saklofske, D. H. (2015). Who is the successful university student? An analysis of personal resources. Canadian Jour- 
nal of Higher Education, 45(2), 214-228. https://doi. org/10.47678/cihe.v45i2.184491

Sternberg, R. J., Grigorenko, E. L., \& Bundy, D. A. (2001). The predictive value of IQ. Merrill-Palmer Quarterly, 47(1), 1-41. https://www.jstor.org/stable/23093686

Stewart, M. J. (1990). Attrition from health professional schools in a Canadian university. Canadian Journal of Higher Education, 20(3), 43-63. https://doi. org/10.47678/cjhe.v20i3.183085

Summerlee, A., \& Murray, J. (2010). The impact of enquiry-based learning on academic performance and student engagement. Canadian Journal of Higher Education, 40(2), 78-94. https://doi.org/10.47678/ cjhe.v40i2.1919

Telling, K. (2018). Selling the liberal arts degree in England: Unique students, generic skills and mass higher education. Sociology, 52(6), 1290-1306. https://doi.org/10.1177/0038038517750548

Trapmann, S., Hell, B., Hirn, J. O. W., \& Schuler, H. (2007). Meta-analysis of the relationship between the Big Five and academic success at university. Zeitschrift für Psychologie/Journal of Psychology, 215(2), 132-151. https://doi.org/10.1027/00443409.215.2.132

Ungar, S. B. (1980). The retention problem: An analysis of enrolment attrition at a Canadian college. $\mathrm{Ca}-$ nadian Journal of Higher Education, 10(1), 57-74. https://doi.org/10.47678/cjhe.v10i1.182808

Von Zur-Muehlen, M. (1978). The PhD dilemma in Canada revisited. Canadian Journal of Higher Education, 8(2), 49-92. https://doi.org/10.47678/ cjhe.v8i2.182764

Waite, S. (2017). Postgraduate wage premiums and the gender wage gap in Canada. Canadian Journal of Higher Education, 47(2), 156-187. https://doi. org/10.47678/cihe.v47i2.187939

Walters, D. (2004). The relationship between postsecondary education and skill: Comparing credentialism with human capital theory. Canadian Journal of Higher Education, 34(2), 97-124. https://doi. org/10.47678/cjhe.v34i2.183458
Wasylkiw, L., Hanson, S., Lynch, L. M., Vaillancourt, E., \& Wilson, C. (2020). Predicting undergraduate student outcomes: Competing or complementary roles of self-esteem, self-compassion, self-efficacy, and mindsets? Canadian Journal of Higher Education, 50(2), 1-14. https://doi.org/10.47678/cjhe. v50i2.188679

Weingarten, H. P., Hicks, M., Kaufman, A., Chatoor, K., MacKay, E., \& Pichette, J. (2019). Postsecondary education metrics for the 21st century. Higher Education Quality Council of Ontario. https://heqco. ca/wp-content/uploads/2020/02/Formatted-Metrics-for-the-21st-Century FINAL.pdf

Wilson, C. A., Babcock, S. E., \& Saklofske, D. H. (2019). Sinking or swimming in an academic pool: A study of resiliency and student success in firstyear undergraduates. Canadian Journal of Higher Education, 49(1), 60-84. https://doi.org/10.47678/ cjhe.v49i1.188220

York, T. T., Gibson, C., \& Rankin, S. (2015). Defining and measuring academic success. Practical Assessment, Research, and Evaluation, 20(1), 1-20. https://doi.org/10.7275/hz5x-tx03

Zelmer, A. E., \& Johnson, N. A. (1988). International students in higher education: A follow-up study of university graduates. Canadian Journal of Higher Education, 18(3), 31-50. https://doi.org/10.47678/ cjhe.v18i3.183044

Ziegler, M., Danay, E., Schölmerich, F., \& Bühner, M. (2010). Predicting academic success with the Big 5 rated from different points of view: Self-rated, other rated and faked. European Journal of Personality, 24(4), 341-355. https://doi.org/10.1002/per.753

\section{Contact Information}

Jason R. Holmes

JRHolmes.yorku@gmail.com 


\section{Appendix}

\begin{tabular}{|c|c|c|}
\hline Category & Author & Year \\
\hline Post-college performance & Adamuti-Trache et al. & 2006 \\
\hline & Archer & 1986 \\
\hline & Beach & 1977 \\
\hline & Colarelli & 1991 \\
\hline & Donaldson \& Dixon & 1995 \\
\hline & Etmanski et al. & 2017 \\
\hline & Fenesi \& Sana & 2015 \\
\hline & Finnie & 2001 \\
\hline & Frank \& Walters & 2012 \\
\hline & McAlpine \& Austin & 2018 \\
\hline & Ralston & 1978 \\
\hline & Redpath & 1994 \\
\hline & Rennie & 1981 \\
\hline & Roessingh \& Douglas & 2012 \\
\hline & Ross et al. & 2018 \\
\hline & Von Zur-Muehlen & 1978 \\
\hline & Waite & 2017 \\
\hline & Walters & 2004 \\
\hline \multirow[t]{9}{*}{ Persistence } & Andres \& Krahn & 1999 \\
\hline & Black & 1972 \\
\hline & Dietsche & 1990 \\
\hline & Grayson & 1995 \\
\hline & Johnson \& Buck & 1995 \\
\hline & Madgett \& Bélanger & 2008 \\
\hline & Stelnicki \& Nordstokke & 2015 \\
\hline & Stewart & 1990 \\
\hline & Ungar & 1980 \\
\hline \multirow[t]{3}{*}{ Academic achievement } & Allan et al. & 1983 \\
\hline & Ayers & 1980 \\
\hline & Grayson & 1997 \\
\hline
\end{tabular}




\begin{tabular}{|c|c|c|}
\hline Category & Author & Year \\
\hline & Grayson & 2001 \\
\hline & Nevitte et al. & 1988 \\
\hline & Roessingh \& Douglas & 2012 \\
\hline & Wilson et al. & 2019 \\
\hline \multirow[t]{4}{*}{ Attainment of educational objectives } & Andres and Looker & 2001 \\
\hline & Christofides et al. & 2015 \\
\hline & Dennison et al. & $1982 a ; 1982 b$ \\
\hline & Etcheverry et al. & 1993 \\
\hline \multirow[t]{7}{*}{ Satisfaction } & Bravo et al. & 2007 \\
\hline & Gomme et al. & 1993 \\
\hline & Grayson & 2004 \\
\hline & Grayson & 2007 \\
\hline & Holdaway \& Kelloway & 1987 \\
\hline & Kilbride \& D'Arcangelo & 2002 \\
\hline & Zelmer \& Johnson & 1988 \\
\hline \multirow[t]{6}{*}{ Acquisition of desired knowledge, skills, and competencies } & Church \& Gillingham & 1988 \\
\hline & Evers and Gilbert & 1991 \\
\hline & Etcheverry et al. & 1993 \\
\hline & Hurst et al. & 2013 \\
\hline & Kanuka \& Cowley & 2017 \\
\hline & Stelnicki et al. & 2015 \\
\hline \multirow[t]{2}{*}{ Engagement } & Beran \& Violato & 2009 \\
\hline & Summerlee \& Murray & 2010 \\
\hline \multirow[t]{3}{*}{ Aboriginal student success } & Gallop \& Bastien & 2016 \\
\hline & Hampton \& Roy & 2005 \\
\hline & Pidgeon et al. & 2014 \\
\hline \multirow[t]{3}{*}{ Psychological/psychosocial factors } & Lisnyj et al. & 2020 \\
\hline & Ramey et al. & 2018 \\
\hline & Wasylkiw et al. & 2020 \\
\hline
\end{tabular}

